\section{Making the Most of Russian Science, and of European Collaboration}

\author{
Volker Reinstorf
}

Volker Reinstorf spent last year evaluating R\&D in Russia, and particularly its links with Europe. He interviewed over seventy researchers, and collated the results of 800 questionnaires. He spent half the year in St. Petersburg, in order, he says, 'to assess the success and limitations of European funding activities and the main needs of Russian scientists now'. While in St. Petersburg he brought together local scientists and representatives of funding bodies for a workshop on scientific collaboration between Russia and Western Europe. He wrote the following summary of his report for Europhysics News.

The largest difficulties experienced in scientific East-West collaborations related neither to science nor to communication, but to money transfer. The difficulties in money transfer in the past years have been so numerous that in most cases the most efficient way of transferring grants was to do it personally by cash.

However, two things should be mentioned in this respect. Firstly, these are mostly problems from the past. Most funding organisations have by now learned from their experiences and have established more or less well-functioning systems. (INTAS, the International Association for the promotion of co-operation with scientists from the New Independent States of the former Soviet Union, for example, has now contracted banks in most of the cities). Secondly, these difficulties never had a sincere impact on the overall satisfaction of the scientists within the funded projects. In this latter respect, the communication with the project coordinator was by far more important and actually turned out to be a key ingredient of successful collaboration.

A second central difficulty in the new independent states (NIS) is receiving information about funding. Even those scientists who had already received funding from a European source knew almost nothing about other European funding possibilities. On the one hand this suggests that information about these programmes still has to be made available to a wider public. But on the other hand, the approach to information still reveals a difference in perception.

Many Russian scientists revealed in their interviews the attitude 'information should be provided for me', and not 'I have to look for information'. Mentioning the fact that the funding organisations could not supply their information directly to millions of scientists in Europe and the former Soviet Union, often resulted in astonishment not to have thought about this simple fact before. The best solution in this respect would be to have one employee in every institution responsible for collecting and distributing information about all funding possibilities. There are already institutes that have organised an internal information system in this way, and the statistics show that they are much more successful in receiving international grants than others.

One particular difficulty for scientists from the NIS is the problem of finding partners from Western Europe for collaborative research projects. Participants in the workshop in St. Petersburg explained that they would often be 'too polite' or 'too shy' to contact Western scientists that they knew only from publications. This is understandable under the circumstances: the Eastern groups receive, in INTAS projects, usually the bulk of the funding, while the Western groups have the duty of managing the administrative aspects of the project.

The most fruitful way to establish scientific co-operation is through personal contacts. The most effective way to establish personal contacts is via scientific conferences. Most of the funded projects had started this way. Since travel costs to conferences have become prohibitively high in comparison to the average salary level,

\section{From the report...}

Despite the fact that many Russian scientists were for a long time isolated from the international scientific community, Russian science was in many areas on a top level in the world. Russia alone had in 1990 three times more scientists and engineers than the entire European Union .

After the breakup of the Soviet Union, the situation for scientists became extraordinarily difficult. Old ties were disconnected, the research budget for basic and civil science has since 1989 dropped by a factor of 50 , and the high reputation of science in Russian society has dropped in a similar manner. The official funding of the science sector in Russia is, in absolute terms, now lower than that of Finland or Argentina, and in \% of GNP, lower than that of Romania.

The average wage of a scientist in Russia is less than US\$100 a month. This is neither enough to feed families, nor enough to stay in science. The situation is especially difficult since living has become much more expensive over the past years. Russia's scientific centres of Moscow and St. Petersburg now belong (as the only European cities) to the ten most expensive cities in the world.

Due to this difficult situation, many scientists have left their positions, either going temporarily or permanently abroad, or finding other, financially more rewarding activities in their own country. This very complex phenomenon, often called brain drain, is not simply bad for society. Its source is the restructuring of the country in the market economy, but when highly educated scientists have second and third jobs far below their qualification, only to come up for a living, it is a loss to Russian society, as well as to science in general.

For the scientists who manage to remain in their home institutions the situation does not look better. Often, the research equipment has become too old to produce relevant scientific results.

conference support - especially travel costs - has to be a major objective for every funding agency. This support should focus on young scientists, since they are usually not yet invited to international conferences.

What is the impact of the funding so far? Besides the fact that for most scientists it offers the possibility of continuing already existing collaborations, the participants of the workshop in St. Petersburg named, in first place, terms like freedom and independence from their administration. It is indeed the case that more than $50 \%$ of the research budget of INTASfunded groups in the NIS comes from 
This situation for scientists in the former Soviet Union very early drew international attention. Already in 1992, the Hungarian-born American billionaire, George Soros, donated US\$100 million via his International Science Foundation (ISF), mainly by providing $\$ 500$ grants to an enormous number of scientists. Even though this programme had its critics ('there was no cheaper way to get an overview of Russia's scientific activities'), George Soros managed to give support to people fast and without bureaucracy, in the most difficult situation right after the breakup of the Soviet Union.

\section{European Funding Actions}

The European Union is involved in three main funding actions supporting co-operation in science and technology with the New Independent States of the former Soviet Union:

- INTAS, the International Association for the promotion of co-operation with scientists from the New Independent States of the former Soviet Union, was founded in 1993. Its member states are the countries of the European Community, Iceland, Israel, Norway, and Switzerland. Average size of projects is $50,000 \mathrm{ECU}$.

- INCO-Copernicus is a programme within the fourth framework programme of the European Union. It is the extension of the PECO-Copernicus programme that was founded in 1992 to support scientific co-operation with the transition countries of Central and Eastern Europe. The average size of INCO-projects is $250,000 \mathrm{ECU}$. -The International Science and Technology Center (ISTC) was established in Moscow in 1994. It was started as a common action from the European Union, the USA, Japan, and the Russian Federation. Since then, Finland, Sweden, Norway, Georgia, Armenia, Belarus, Kazakstan, and the Kyrgyz Republic have acceded to the agreement and statutes. So far, the ISTC has funded 391 projects with an average of US $\$ 350,000$.

international sources. National public funds cover only $44 \%$, while private funding is still absolutely negligible. At this time of rapid transformation and restructuring, enterprises are often much more involved in trade than in anything else, and find neither the time nor the means, nor the will, for long-term investments in research and development. But for the long-term perspectives of the Russian economy and, therefore, for stable conditions in the future, it is definitely necessary to keep and develop Russia's scientific potential. Also, in view of the fact that international support actions will not continue forever, it would be very desirable, if not necessary, to increase the awareness of this important fact in the new Russian private sector.

One of the main effects international funding organisations can have, apart from the purely financial aspect, is to teach management. NIS researchers who actively participated in the organisation of their international projects usually had no problems organising other grants afterwards. It was very interesting to find in interviews with project participants in the NIS, how some of them had even founded their own new institutes, mainly financed via international sources.

A central problem in the current situation in the NIS is that young scientists experience much larger difficulties in obtaining grants than the heads of research groups. Already established researchers often have the possibility of giving some lectures for money, to be invited to conferences, or use their knowledge in other profitable ways. But the young generation that cannot yet present significant scientific results is particularly struck by the financial difficulties, especially since travel costs have become prohibitively high.

Maybe the most fruitful approach in this respect are bilateral contacts, for example exchange programmes between universities. But also the placement of young researchers in Western research institutions, for a period of about six months in the framework of international research projects, could have a large impact. These young 'missionaries' could promote the work of the Russian group in the West, establish more stable contacts, and the obtained language skills would be of benefit for the whole group in their home institution.

The overall need of research groups in the NIS today is the lack of individual grants (more than $60 \%$ of the scientists rated this as 'need number one'). Even though this fact is independent of the scientific area, a sincere difference exists between theoretical and experimental groups. For many experimental research groups the situation has qualitatively changed over the past five years. Often, research equipment has become too old to produce relevant scientific results. And if the equipment does not allow sincere scientific work anymore, individual grants do not help.

Unfortunately, prices for modern research equipment in physics and other experimental sciences are prohibitively high for the limited resources of funding organisations like INTAS. But there is no way around it: if one wants to save the experimental know-how that Russia has built up over the past fifty years, the international community has to find ways to support international scientific co-operation at experimental research centres with competitive equipment in Russia. One might for, example, consider the possibility of equipping selected, internationally renowned institutes with key equipment via an international budget. These centres would enhance international scientific cooperation by attracting researchers from the West to Russia, which is today too uncommon. Actions like these could be a key ingredient in enhancing links between Russia and the Western community.

One participant of the workshop at St. Petersburg painted a very plastic picture of the current situation in Russia: Russia is currently in a phase transition. During a phase transition, there is a lot of chaos and many things are not understood. But in every phase transition, there are points of crystallisation: the points of future growth. The main duty of the funding organisations would be to identify these points of future growth and support them to become a network of self-carrying structures.

This idea, which sounds abstract, is actually a very practical one indeed. In Russian society there are currently active groups scattered and people who do excellent work and go innovative ways. New, small universities with a motivated staff teach the young generation history and market economy. Famous scientific institutions organise summer schools for students from Western Europe. Other organisations try to build a link between the still large scientific sector and new firms in the Russian market economy. All of these actions fight every day against extraordinary financial difficulties, and many die again.

In general, there is no alternative to the current peer review system for projects as currently applied by the funding organisations. But one might also try to go new ways. For example: ask twenty internationally famous scientists to name twenty excellent and innovative groups in the NIS. Then make cross references between the 400 nominations. These could be some 'points of crystallisation', the points of future growth in Russia, and these would definitely be worth further support. Support of the Robert Bosch Foundation, INTAS, the European Commission and the ISTC in all practical and financial ways is greatly appreciated by the author 